\title{
The Effect of Liquidity Ratio and Activity Ratio on Profit Growth with Company Size, Leverage, and Return on Assets as Control Variables in Coal Mining Companies Listed on the Indonesia Stock Exchange
}

\author{
Adriana Viyanti Idi ${ }^{1}$, Sari Yuniarti ${ }^{2}$, and Sunardi ${ }^{3}$ \\ ${ }^{1}$ Student in Magister Management Program, University of Merdeka Malang, Indonesia \\ ${ }^{2,3}$ Lecturer in Faculty of Economics and Business, University of Merdeka Malang, Indonesia
}

\begin{abstract}
This study aims to analyze the effect of the liquidity ratio (current ratio) and activity ratio (total asset turnover) on profit growth with firm size, leverage, and return on assets as control variables. The population in this study are mining companies listed on the Indonesia Stock Exchange for the 2015-2019 period. The data used in this study is the financial statements of mining companies listed on the Indonesia Stock Exchange. The analytical method used is the quantitative method, while the analytical technique used is panel data linear regression, and partial hypothesis testing using $t$ - test. The results showed that the results of the F test on the variable current ratio $(C R)$ and total asset turnover had a significant positive effect on profit growth. The results of the t-test indicate that the current ratio $(C R)$ and total asset turnover have a significant positive effect on profit growth. This study supports the results of research conducted by Suyono (2020) which states that the liquidity ratio (current ratio) has a significant effect on profit growth.
\end{abstract}

Keywords: Current Ratio, Total Asset Turnover, Profit Growth.

\section{INTRODUCTION}

Mining companies are one of the industries that experience fluctuating conditions. Mining companies in their contribution to the economy in Indonesia, one of which is in the coal mining sub-sector which is also one of the industries that contributes to state revenues. Although not as big as other mining, where its role is also as a provider of energy resources that are needed for the economic growth of a country. The condition of mining companies can be interpreted as the company's performance. Where the company's performance is a very important factor to find out whether the company is progressing or vice versa.

A company can be categorized as achieving success and success if it wins a competition to get maximum profit. According to Samryn (2012:429) profit is an internal source of funds that can be obtained from normal company activities that do not require extra costs to store their use. Therefore, if the company's performance is good then profit growth increases, and vice versa if the company's performance is not good then profit growth decreases. In this case, profit growth is an increase in profits obtained by the company compared to the previous year. [1].

Research conducted by Sari (2015) states that profit growth is a ratio that shows the company's ability to increase net income compared to the previous year, the higher the profit growth ratio the better the financial performance of a company. Then the research conducted by Prihartanty (2010) also said that the increasing profit growth from year to year will give a positive signal about the company's performance. [2-3].

Financial statements are an important component because they provide information that is used for decision making. The parties with an interest in the financial statements are investors, potential investors, the financiers to the management of the company. It is important for users of financial statements to know profit growth because the increase in profits earned by the company determines the rate of return to shareholders or for potential investors to make decisions in investing in the company.

Hermani (2020) states that the ability to maintain profit growth will determine the rate of return on equity to shareholders or to investors and this action will increase the confidence of creditors and potential investors in making decisions. [4].

This study aims to analyze the effect of the liquidity ratio and activity ratio on profit growth with company size, leverage, and ROA, as control variables in coal mining companies listed on the Indonesia Stock Exchange. 


\section{LITERATURE REVIEW}

\section{a. Liquidity Ratio}

The liquidity ratio describes how the company's ability to pay off short-term obligations (short-term debt). If the company has the ability to pay or pay off its short-term debt when it matures, it can be said that the company is a liquid company.

The type of liquidity ratio used in this study is the current ratio. Current Ratio (current ratio) is a ratio used to measure the company's ability to pay its short-term obligations by using its current assets. If the ratio of current debt exceeds current assets, the company is said to have difficulty paying off its short-term debt. If the current ratio is too high, then a company is said to be less efficient in managing its current assets, this is explained by Suad (2013: 344) if the current ratio is too high (a value of more than $100 \%)$, then the company does not use current assets efficiently. [5].

\section{b. Activity Ratio}

The activity ratio describes the activities carried out by the company in carrying out its operations in selling, purchasing, and other activities. In this study, the type of activity ratio used is Total Asset Turnover (TATO). Total Asset Turnover is the ratio between the amount of assets used and the amount of sales earned during a certain period. This ratio is also a measure of how far assets have been used in company activities or shows how many times the assets rotate in a certain period.

\section{c. Control Variable}

The controlling factor in this study uses Company Size, Leverege, and ROA. With the aim that the results obtained can improve the consistency of the results of the analysis to be carried out. Research conducted by Rantika (2016) with the title The Effect of Financial Ratios on Profit Growth in Metal Mining Companies on the IDX, based on the results studied by the current ratio, debt to equity ratio, which has a significant effect on profit growth. Meanwhile, net profit margin and total asset turnover have no significant effect on profit growth. [6].

\section{d. Conceptual Framework}

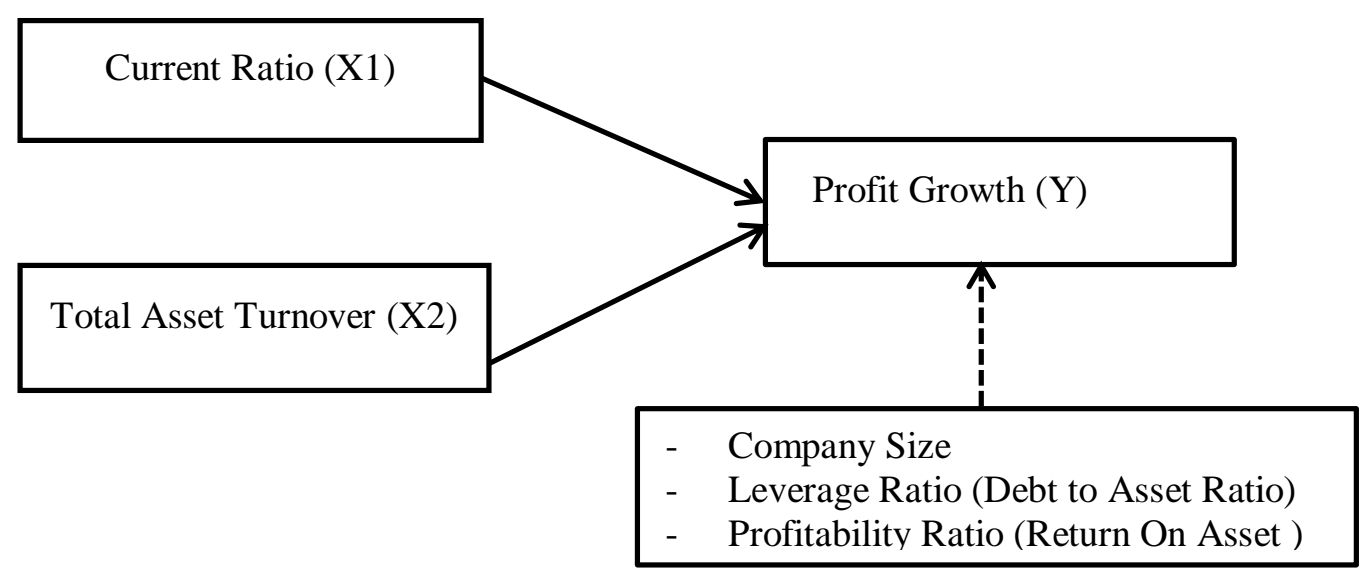

Figure 1: Conceptual Framework

Information:

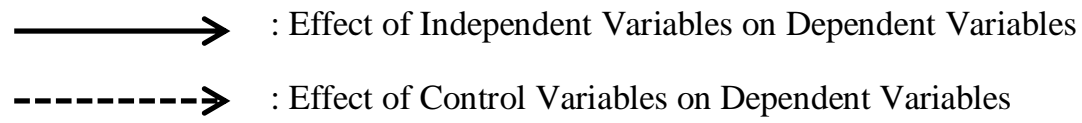

\section{e. Hypothesis}

The hypotheses in this study are:

1) Current ratio has a significant positive effect on profit growth.

2) Total asset turnover has a significant positive effect on profit growth.

3) Ratio Current ratio, Total asset turnover, together (simultaneously) have a significant positive effect on profit growth.

\section{RESEARCH METHOD}

\section{a. Population and Sampling Techniques}

The population in this study are all banking companies listed on the Indonesia Stock Exchange as many as 23 companies. This study uses panel data with a total of 115 observations ( $n$ ) data (Unbalanced panel data) taken from the documentation of the annual financial statements of coal mining companies for the 2015-2019 period. This type of research is a causal associative that 
explores the effect of liquidity ratios and activity ratios on profit growth with company size, leverage and ROA as control variables in coal mining companies listed on the Indonesia Stock Exchange for the 2015-2019 period.

\section{b. Research Variable}

The dependent variable in this study is profit growth, which describes how much increase in profits owned by a company. Profit growth can be formulated as follows:

$$
\text { Profit growth }=\frac{\text { net profit this year-net profit last year }}{\text { net profit last year }}
$$

The first independent variable in this study is liquidity (current ratio). The current ratio describes the company's ability to meet its short-term debt by using its current assets (assets that will turn into cash within one year or one business cycle). A low ratio indicates a high liquidity risk while a high current ratio indicates an excess of current assets which will have an adverse effect on the company's profitability. This current ratio can be measured by the formula:

$$
\text { Current Ratio }=\frac{\text { Current Assets }}{\text { Current Liabilities }} \times 100 \%
$$

The second independent variable in this study is the activity ratio (total asset turnover). total asset turnover is a ratio used to "show how effective the company is in using its overall assets to create sales and earn profits. The ratio of total asset turnover (total asset turn over) is measured by the formula:

$$
\text { Total Asset Turn Over }=\frac{\text { Sales }}{\text { Total Asset }}
$$

There are 3 control variables in this study, namely firm size (size), leverage, and return on assets. Company size is the size of the company seen from the amount of equity value, sales value or asset value. Leverage is a ratio used to measure how much the company's assets are financed by debt or how much the company's debt affects asset management. And return on assets is a ratio that shows the company's ability to make profits.

$$
\begin{aligned}
& \text { Company Size }=\text { Ln }(\text { Total Assets }) \\
& \text { Total Debt to Asset Ratio }=\frac{\text { Total Debt }}{\text { Total Assets }} \times 100 \% \\
& \text { Retrun On Assets }=\frac{\text { Earning After Tax }}{\text { Total Aktiva (Total Asset) }} \times 100 \%
\end{aligned}
$$

\section{RESEARCH RESULT}

The data analysis technique used in this study is panel data regression with the help of the E-views 10 program. The selection of panel data is due to the fact that this study uses a time span of several years and also many companies. The first is to use time series data, namely from 2015-2019. Then the use of the cross section itself because this study takes data from many companies (pooled) consisting of 23 coal mining companies that go public. The structural equation for panel data regression is shown in the following equation:

$$
\text { EATgrowth }_{i t}=\alpha+\beta_{1} \mathrm{CR}_{\mathrm{it}}+\beta_{2} \mathrm{TATO}_{\mathrm{it}}+\beta_{3} \mathrm{SIZE}_{\mathrm{it}}+\beta_{4} \mathrm{DAR}_{\mathrm{it}}+\beta_{5} \mathrm{ROA}_{\mathrm{it}}+\mathrm{e}_{\mathrm{it}}
$$

$$
\begin{aligned}
& \text { EATgrowth }_{i t}=\text { Profit Growth } \\
& \text { CRit }=\text { Current Ratio } \\
& \text { TATOit }=\text { Total Asset Turnover } \\
& \text { SIZEit }=\text { Company Size } \\
& \text { ROAit }=\text { Return on assets } \\
& \alpha=\text { Intercept/constant } \\
& \beta 1,2,3,4,5=\text { Regression coefficient } \\
& \text { eit }=\text { Error }
\end{aligned}
$$




\section{a. Descriptive Statistics Results}

Descriptive analysis is used to describe or describe the variables in this study seen from the average value, standard deviation, maximum value and minimum value. The variables used in this study are the liquidity ratio (current ratio), activity ratio (total asset turnover), firm size, leverage, and return on assets (ROA). The processed results of descriptive statistics are presented in table 1.

Table 1. Descriptive Statistics

\begin{tabular}{|l|c|c|c|c|c|c|}
\hline & CR & TATO & Com.Size & Leverage & ROA & $\begin{array}{c}\text { Profit } \\
\text { Growth }\end{array}$ \\
\hline Mean & 4,244829 & 0,754135 & 18,52554 & 0,541072 & 0,052450 & 1,334405 \\
\hline Median & 1,636000 & 0,680000 & 18,97400 & 0,435000 & 0,046000 & $-0,140000$ \\
\hline Maximum & 146,1300 & 2,249000 & 22,06200 & 5,961000 & 0,456000 & 68,45300 \\
\hline Minimum & 0,099000 & 0,005000 & 12,69800 & 0,098000 & $-0,644000$ & $-8,228000$ \\
\hline Std. Dev. & 17,19190 & 0,523764 & 2,678352 & 0,593932 & 0,148027 & 7,417594 \\
\hline Jarque-Bera & 14164,87 & 5,796976 & 11,46300 & 18221,67 & 246,0911 & 17065,56 \\
\hline Probability & 0,000000 & 0,055106 & 0,003242 & 0,000000 & 0,000000 & 0,000000 \\
\hline Sum & 471,1760 & 83,70900 & 2056,335 & 60,05900 & 5,822000 & 148,1190 \\
\hline Sum Sq. Dev. & 32511,77 & 30,17617 & 789,0927 & 38,80314 & 2,410321 & 6052,277 \\
\hline Observations & 111 & 111 & 111 & 111 & 111 & 111 \\
\hline
\end{tabular}

Source: Processed secondary data (2021)

Based on the results of descriptive statistics (table 1), the average current ratio (CR) value of 4,244 is in the poor category based on the current ratio (CR) assessment standard. Total asset turnover has an average value of 0.754 which means it is not good because it is in a position that is not liquid from the industry standard by 2 times.

\section{b. Test Result of Selection of Panel Data Regression Model Estimation}

In selecting the panel data estimation used, it is necessary to perform the Chow Test to choose between the Common Effect Model (CEM) or Fixed Effect Model (FEM) and the Hausman Test to choose between the Fixed Effect Model (FEM) or the Random Effect Model (REM).

The results of the Chow test resulted in a probability $\mathrm{F}$ value of $0.278>0.05$, so the model chosen was the Common Effect Model (CEM). Therefore, the next test was carried out with the Hausman test.

Based on the Hausman test, the probability value of $\mathrm{F}$ is $0.788>0.05$, so the model chosen is the Random Effect Model (REM). Then the next Lagrange Multiplier Test is carried out, the results obtained are the probability $\mathrm{F}$ value of $0.067>0.05$, so the model chosen is the Common Effect Model (CEM). Therefore, based on the three model selection tests that have been carried out, it is concluded in this study using the Common Effect Model (CEM).

\section{c. Classical assumption test results}

\section{1) Normality Test}

The normality test in this study uses the E-views 10 program. The normality of a data can be determined by comparing the JarqueBera (JB) and Chi-Square values. Based on the data processing, the Jarque-Bera probability value is 170.766 and the Chi-Square probability value is 0.068 , where these results are above the $0.05 \%$ significance level so that it is concluded that there is no normality problem.

\section{2) Multicollinearity Test}

Based on the results of multicollinearity testing, five correlation values can be obtained for the current ratio (CR), total asset turnover (TATO), firm size, leverage and return on assets with each $0.675021,0.287945,0.165688,0.746848$, and 0.283133 . of the five correlation values are smaller than 0.80 and it can be concluded that there is no multicollinearity.

\section{3) Heteroscedasticity Test}

Based on heteroscedasticity testing, five probability values can be obtained from the current ratio (CR), total asset turnover (TATO), firm size, leverage and return on assets, respectively $0.0573,0.995,0.083,0.8649$ and 0.199 . The three probability values are greater than 0.05 , so it can be concluded that there is no heteroscedasticity problem.

\section{d. Results of Panel Data Regression Testing with Generalized Least Squares Approach}

The results of panel data regression testing use 2 (two) test models, namely the F test (simultaneous) and the $t$ test (partial). The $\mathrm{F}$ test is a simultaneous regression relationship test which aims to determine whether all independent variables together have a significant effect on the dependent variable. The $t$ test is used to partially test the hypothesis in order to show the effect of each independent variable individually on the dependent variable. Table 2 presents the results of the panel data regression test. 
International Journal of Advances in Scientific Research and Engineering (ijasre), Vol 7 (10), October -2021

Table 2. Results of Panel Data Regression Analysis with Generalized Least Squares Approach

\begin{tabular}{|c|c|c|c|c|}
\hline Variable & Coefficient & Std. Error & T-Statistic & Prob. \\
\hline CR & 0.122739 & 0.032821 & 3.739628 & 0.0003 \\
\hline TATO & 3.074793 & 1.130961 & 2.718743 & 0.0077 \\
\hline Com_Size & 0.063196 & 0.167684 & 0.376873 & 0.7070 \\
\hline Leverage & 6.827480 & 0.951870 & 7.172704 & 0.0000 \\
\hline ROA & -0.190148 & 4.166464 & -0.045638 & 0.9637 \\
\hline C & -6.360332 & 3.181628 & -1.999081 & 0.0482 \\
\hline R-Squared & 0.665538 & \multicolumn{2}{|c|}{ Mean Dependent Var } & 1.334405 \\
\hline $\begin{array}{c}\text { Adjusted R- } \\
\text { Squared }\end{array}$ & 0.649611 & \multicolumn{2}{|c|}{ S.D. Dependent Var } & 7.417594 \\
\hline S.E. Of Regression & 4.390745 & \multicolumn{2}{|c|}{ Akaike Info Criterion } & 5.849413 \\
\hline Sum Squared Resid & 2024.257 & \multicolumn{2}{|c|}{ Schwarz Criterion } & 5.995874 \\
\hline Log Likelihood & -318.6424 & Hannan-Quinn Criter. & 5.908828 \\
\hline F-Statistic & 41.78740 & \multicolumn{2}{|l}{ Durbin-Watson Stat } & 1.763741 \\
\hline Prob(F-Statistic) & 0.000000 & \multicolumn{5}{l}{} \\
\hline
\end{tabular}

Source: Processed secondary data (2021)

Based on table 2, the probability value of $\mathrm{S}$ statistic is $0.000000<0.05$. This shows that the current ratio and total asset turnover simultaneously have a significant effect on profit growth.

Based on table 2, the results of the effect of the current ratio on profit growth obtained a probability value of 0.0003 , where this value is significant because it is smaller than $=0.05$, which means that the current ratio has a significant positive effect on profit growth. Total asset turnover obtained a probability value of 0.0077 , where this value is significant because it is smaller than $=0.05$, which means that total asset turnover also has a significant positive effect on profit growth

While the control variable company size has a probability value of 0.7070 , where this value is not significant because it is greater than $=0.05$, which means that the size of the company has no significant effect on profit growth. Then leverage has a probability value of 0.0000 where this value is significant because it is smaller than $=0.05$, which means that leverage has a significant positive effect on profit growth. And return on assets has a probability value of 0.9637 , where this value is not significant because it is greater than $=0.05$, which means that company size has no significant effect on profit growth.

Based on the results of panel data regression testing, the structural equations for panel data regression using the Generalized Least Squares approach are formed:

EATgrowth $=-6,360332+0,122739 \mathrm{CR}+3,074793 \mathrm{TATO}+0,063196 \mathrm{SIZE}+6,827480 \mathrm{DAR}-0,190148 \mathrm{ROA}+\mathrm{e}$

\section{DISCUSSION}

\section{a. Effect of Current Ratio (CR) on Profit Growth}

Based on the results of the study indicate that the current ratio has a significant positive effect on profit growth in coal mining companies. The results of this study are in line with research conducted by Suyono (2020) in his research results stating that the Current Ratio and Total Asset Turnover have a significant positive effect on profit growth in mining companies listed on the Indonesia Stock Exchange. [7].

This study also supports the signal theory that companies that are able to generate profits tend to increase their debt, because the additional interest payments will be offset by profit before tax. if the variable current ratio (CR) increases, profit growth will also increase.

The current ratio (CR) is the company's ability to pay its short-term obligations or current debts that are due immediately when they are billed in their entirety. where the company's good ability to manage its current assets against current liabilities, which as a whole can guarantee the availability of working capital to support the operational activities of coal mining companies.

The company's liquid financial condition can also help funding investors and creditors in providing credit to the company, so that the company's operational activities will continue to run smoothly.

Thus it can increase profit growth in the coal mining company itself. As for what must be considered in the current ratio (CR), that is, if the value is more than the industry standard, which is $200 \%$, it does not mean that the company's financial condition is good, but on the contrary, the company does not allocate its current assets optimally, does not utilize its current assets efficiently and does not manage its capital properly. 


\section{b. The Effect of Total Asset Turnover (TATO) on Profit Growth}

Based on the results of the study indicate that total asset turnover has a significant positive effect on profit growth in coal mining companies. This result is also in line with research conducted by Megananda (2017) in his research results which also states that Total Asset Turnover (TATO) has a significant effect on profit growth. [8].

Total asset turnover (TATO) is a ratio used to measure the total asset turnover of the company, where the asset turnover is used to see whether the company is able to manage its total assets to obtain sales.

With a large total asset value, the better the assets can rotate faster, so they can be used by the company to create sales. the more opportunities from the company to increase the sales value, it is believed that it has the potential to increase profit growth in coal mining companies.

\section{CONCLUSIONS AND RECOMMENDATIONS}

This study aims to analyze the effect of the liquidity ratio (current ratio) and activity ratio (total asset turnover) on profit growth with company size, leverage and return on assets in coal mining companies for the 2015-2019 period. The results of the study prove that the current ratio has a significant positive effect on profit growth. That the company has the ability to meet its short-term obligations so as to guarantee the availability of working capital to support the company's operational activities, so as to increase profit growth.

Then also obtained the results of total asset turnover partially positive significant effect on profit growth. Where shows that the company is able to manage all of the company's assets very well so that there is a good suitability of asset turnover which can increase profit growth. And also proves that the current ratio and total asset turnover have a significant positive effect simultaneously on profit growth in coal mining companies listed on the Indonesia Stock Exchange for the 2015-2019 period.

Further research is expected to be able to add other variables not included in this study so that the results obtained are more varied which can describe what things affect profit growth and increase the number of samples in the research to be carried out in order to increase the scope of research results by using research analysis methods. which will be used in future research.

\section{REFERENCES}

1. Samryn, L. M. (2014). Introduction to Accounting: easy journaling with transaction cycle approach. Jakarta: Rajawali Press

2. Sari, L. P., \& Widyarti, E. T. (2015). Analysis of the Effect of Financial Ratios on Profit Growth (Case Study: Food and Beverages Companies listed on the Indonesia Stock Exchange for the period 2009 to 2013) (Doctoral dissertation, Faculty of Economics and Business)

3. Prihartanty, R. (2010). Analysis of the Effect of Liquidity Ratios, Leverage Ratios, Activity Ratios, and Profitability Ratios on Net Income Growth (Study on Retail Trading Companies Listed on the Indonesia Stock Exchange for the period 2005-2009). Diponegoro University

4. Hermani, V. O. F. (2020). The Effect of Leverage Ratio, Profitability, and Liquidity on Company Profit Growth (Empirical Study: Animal Feed Companies Listed on the Stock Exchange in 2012-2018). Yogyakarta Sanata Dharma University

5. Husnan, Suad. (2013). Financial Management Fourth Edition. Yogyakarta: BPFE.

6. Rantika, D. R., \& Budiarti, A. (2016). The Effect of Financial Ratios on Profit Growth in Metal Mining Companies on the IDX. Journal of Management Science and Research (JIRM), 5(6)

7. Suyono, S., \& Marina, M. (2020). Analysis Of The Effect Of Financial Ratio On Profit Growth In Mining Companies Listed On The Indonesia Stock Exchange For The Period Of 2013-2017. Bilancia: Scientific Journal of Accounting, 4(1), 1-10.

8. Megananda, B. A., \& Sitohang, S. (2017). Effect of Current Ratio, Total Asset Turnover and Return on Assets on Profit Growth. Journal of Management Science and Research (JIRM), 6(10) 